\title{
IDENTIFICATION OF BACTERIA IN RAINWATER SAMPLES FROM MAKANA LOCAL MUNICIPALITY IN SOUTH AFRICA
}

\author{
Tererai NHOKODI, Thandiswa NQOWANA, C. S. DUBE, R. TANDLICH ${ }^{1}$
}

\begin{abstract}
Identification of Bacteria in Rainwater Samples From Makana Local Municipality in South Africa. Climate change has been linked to the changes in the rates of diarrhoeal infectious diseases in the Southern African subcontinent. This leads to the increased significance of water, sanitation and hygiene (WASH) in public health in countries like South Africa. A study was conducted to identify bacteria providing a positive signal in the improved hydrogen-sulphide test kit. This was accomplished using the API20E test kit and the APIWEB database. Results of the bacterial identification show that $52 \%$ of all bacterial species isolated from the faecally-contaminated samples were identified as Enterobacter cloacae. Seventeen percent of strains were identified as Serratia liquefaciens and $4 \%$ as Enterobacter amnigenus. Finally, $30 \%$ of the bacterial strains could not be identified. These are all potential human pathogens, if the sampled rainwater is used for potable purposes. Therefore treatment must be implemented before the water is used for potable purposes. Regular microbial water quality monitoring should also be performed using citizen science and some relevant approaches are proposed.
\end{abstract}

Keywords: WASH, API 20E, hydrogen-sulphide test kit

\section{INTRODUCTION}

Climate change has been linked to shifts in the rates of diarrhoeal infectious diseases in the Southern African subcontinent (Shuman, 2010). These diseases are often the result of inadequate water supply or sanitation. Being a water-stressed region, South Africa has experienced water shortages and occasional droughts (Jury and Levey, 1993; Otieno and Ochieng, 2004; Ngaka, 2012). A major problem from the public health point of view is still provision of drinking water around the country (Luyt et al., 2012).

This leads to the increased significance of water, sanitation and hygiene (WASH) in public health in South Africa. Makana Local Municipality (designated as Makana in further text) forms part of the Cacadu District Municipality and municipal drinking water supply is often interrupted (Nhokodi et al., 2016). Microbial water quality of the municipal drinking water supply has been shown not adhere to the South African drinking water standards (Nhokodi et al., 2016). This forces the population to turn to alternate sources of potable water (Nhokodi et al., 2016). Microbial water quality of these alternative sources must be known as this

1 Division of Pharmaceutical Chemistry, Faculty of Pharmacy, Rhodes University, P.O. Box 94, Grahamstown 6140, South Africa, Tel 00-27-46-603-8825, Fax 00-27-46-603-7506, *corresponding author, e-mail: roman.tandlich@gmail.com 
information is of critical importance from the public health point of view (Tandlich et al., 2014).

Information about the presence/absence of potential human pathogens in rainwater in South Africa is still limited in scientific literature. In this short paper, we seek to present the results of identification of the faecal bacteria present in rainwater sampled at the Rhodes University campus in the Grahamstown area of Makana. The bacteria were isolated from positive samples in the improved hydrogen-sulphide test kits (designated as kit in further text; Luyt et al., 2011).

\section{METHODS AND MATERIALS}

Three sampling sites with rainwater harvesting and storage tanks were identified around Rhodes University campus and were sampled on six occasions between April and July 2016 (Nhokodi et al., 2016). To eliminate any false negative results, all kits with sampled rainwater were incubated at $35-37^{\circ} \mathrm{C}$ for 72 hours. A positive faecal contamination was indicated by a black colour after 72 hours of incubation in five replicate kits taken a single sampling site on a single sampling occasion.

The aim was to identify potential pathogens which either produce a positive signal in the kit or which can grow in the kit medium without producing a positive H2S signal, but when a positive signal is detected. Subsamples were removed from the positive kits using an inoculation loop and transferred onto nutrient agar (Merck Pty/Ltd., Cape Town/Johannesburg, South Africa).

Aerobic and facultative anaerobic bacteria were isolated from the water samples which were positive for faecal contamination using nutrient agar. The nutrient agar was prepared according to the manufacturer's instructions and poured into $90 \mathrm{~mm}$ sterile plastic Petri dishes (Spellbound Labs, Port Elizabeth, South Africa). The inoculated plates were incubated at $37^{\circ} \mathrm{C}$ for 24 hours.

After this, 25 bacterial strains were isolated and re-streaked once onto fresh nutrient agar plates. Once the growth was observed on the second batch of nutrient agar plates, the resulting cultures were transferred onto nutrient agar slants. All incubations were again performed at $37{ }^{\circ} \mathrm{C}$ for 24 hours. Slants with visible bacterial cultures were removed from the incubator and stored at $4{ }^{\circ} \mathrm{C}$ until the identification could be performed.

Identification of the isolated strains was performed using the API 20E system and the APIWEB online database (Biomerieux, Midrand, South Africa). For this, the nutrient agar slants with isolated bacteria were brought to nutrient temperature and inoculated into nutrient broth using an inoculation loop. The bacteria were grown at $37{ }^{\circ} \mathrm{C}$ for 48 hours and the identifications were all performed according to the manufacturer's instructions. All incubations were done in one of the following incubators: the Labcon incubator Model FSIM B (Labmark, Johannesburg, South Africa), the Labcon low temperature incubator LTIE 10 (Labmark, Johannesburg, RSA); and/or the Heraeus Model FT 420 (Heraeus 
Kulzer GmbH, Dormagen, Germany). All sterilisations were performed in the Model RAU-53Bd REX MED autoclave (Hirayama Manufacturing, Tokyo, Japan).

\section{RESULTS AND DISCUSSION}

Out of the 25 isolated strains, re-inoculation and identification was successful for 23 strains. The other two strains did not remain viable after the storage on slants at $4{ }^{\circ} \mathrm{C}$. Twelve strains were identified as Enterobacter cloacae with the probabilities of correct identification in the API 20E system ranging from 62.7 to $99.6 \%$. Four of the isolated bacterial strains were identified as Serratia liquefaciens with the probability of correct identification being negligible to 69.8 to $95.5 \%$.

One strain was identified as Enterobacter amnigenus with the probability of correct identification equal to $96 \%$. Results for 7 strains were inconclusive using the API20E system. Bacteria belonging to the Enterobacter spp. have been detected in rainwater in South Africa before (Nevondo and Cloete, 1999). Enterobacter cloacae can be of environmental origin, and might be the causative agents of human infections (Thornsberry, 2003; Cabral, 2010). Serratia liquefaciens is normally associated with plant tissue (Labbate et al., 2004), but strains of this bacterium have been as linked to ophthalmic infections in humans (Pinna et al., 2011).

The most likely source of Enterobacter cloacae were faeces of birds, while Serratia liquefaciens was likely deposited onto the roof of the catchments with plants material. As neither of the rainwater tanks had firstflush devices or any other filter/treatment system installed, the plant debris could have been carried into the rainwater harvesting tank. This in turn resulted in the contamination of stored/sampled rainwater. Enterobacter amnigenus is also a human pathogen (Capdevilla et al., 1998) and this is the first report of its suspected detection in rainwater based on the authors' search of available literature.

The data from the current study indicated that the rainwater at Rhodes University campus contains potential human pathogens. The water is used to supplement the water requirements during a municipal potable water outage (Nhokodi et al., 2016). The current results suggested that the rainwater needs to be treated before human consumption and its microbial quality should be monitored regularly using previous reported approaches, e.g. using citizen science using the student environmental representatives as described previously (Nhokodi et al., 2016). As many of the students at Rhodes University use English as second language, an outline for the correct use of the kit and the treatment of rainwater, published previously by the authors (Tandlich et al., 2014), has been translated into isiXhosa (a local 
African language in Makana). It will be used in the future water monitoring efforts.

\section{CONCLUSION}

Results of the bacterial identification showed that $52 \%$ of the isolated bacterial species were identified presumptively as Enterobacter cloacae. Seventeen percent of strains were identified as Serratia liquefaciens and $4 \%$ as Enterobacter amnigenus. Finally, $30 \%$ of the bacterial strains could not be identified. Consulting literature indicates that rainwater in South Africa can be the source of potential human pathogens. Therefore treatment must be implemented before the water is used for potable purposes. Regular microbial water quality monitoring should also be performed. As the kit is easy to use and laypersons can be trained to perform the testing using the test kit, concepts of citizen science can be used to carry the testing using platforms already in place.

\section{REFERENCES}

1. Apiweb ${ }^{\mathrm{TM}}$. Identification of bacteria using API http://www.slideshare.net/nomanfarrukh3/api-20-e accessed on October, 25, 2016.

2. Cabral, J.P.S. (2010), Water Microbiology. Bacterial Pathogens and Water. International Journal of Environmental Research and Public Health, 7(10), 36573703.

3. Capdevilla, J.A., Bisbe, V., Gasser, I., Zuazu, J., Olivé, T., Fernández, F., Pahissa Berga A. (1998), Enterobacter amnigenus: An unsual human pathogen. Enferm. Infecc. Microbiol. Clin., 16(8), 364-366.

4. Jury M.R., Levey K. (1993), The climatology and characteristics of drought in the Eastern Cape of South Africa, International Journal of Climatology, 13(6), 626641.

5. Labbate, M., Queck, S.Y., Koh, K.S., Rice, S.A., Givskov, M., Kjelleberg, S. (2004), Quorum sensingcontrolled biofilm development in Serratia liquefaciens MG1. Journal of Bacteriology, 186, 692-698.

6. Luyt, C.D., Tandlich, R., Muller, W.J., Wilhelmi, B.S. (2012), Microbial monitoring of surface water in South Africa. International Journal of Environmental Research and Public Health, 9(8), 2669-2693.

7. Luyt, C.D., Muller, W.J., Tandlich, R. (2011), Factors influencing the results of microbial surface water testing in South Africa. International Journal of Medical Microbiology, 301(S1), 28-29.

8. Nevondo, T.S., Cloete, T.E. (1999), Bacterial and chemical quality of water supply in the Dertig village settlement. Water SA, 25(2), 215-220.

9. Ngaka, M.J. (2012), Drought preparedness, impact and response: A case of the Eastern Cape and Free State provinces of South Africa. Jàmbá: Journal of Disaster Risk Studies, 4(1), Article \#47, 10 pages, http://dx.doi.org/10.4102/jamba.v4i1.47.

10. Nhokodi, T., Nqowana, T., Collings, D., Tandlich, R., Köhly, N. (2016), Civic engagement and environmental sustainability in teaching and learning at a higher education institution in South Africa. Acta Technologica Dubnicae, 6(3), in press. 
11. Otieno F.A.O., Ochieng G.M.M. (2004), Water management tools as a means of averting a possible water scarcity in South Africa by the year 2025, Water SA, 30(5), 668-672.

12. Pinna, A., Usai, D., Sechi, L.A., Carta, A., Zanetti, S. (2011), Detection of virulence factors in Serratia strains isolated from contact corneal ulcers. Acta Ophthalmologica, 89(4), 382-387.

13. Shuman, E. K. (2010), Global climate change and infectious diseases. New England Journal of Medicine, 362, 1061-1063.

14. Tandlich, R., Luyt, C. D., Ngqwala, N. P. (2014), A community-based rainwater monitoring and treatment programme in Grahamstown, South Africa. Journal of Hydrocarbons, Mines and Environmental Research, 5(1), 46-51.

15. Thornsberry, C. (2003), Antibiotic Susceptibility of Common Bacterial Pathogens Causing Hospital-Acquired Pneumonia. Presented at the 43rd ICAACA meeting of the American Society for Microbiology, held in Chicago, IL from 14th until 17th September 2003. 